\title{
Cold storage in salicylic acid increases enzymatic and non-enzymatic antioxidants of Nam Dok Mai No. 4 mango fruit
}

\author{
Chanikan Junmatong ${ }^{\mathrm{a}}$, Bualuang Faiyue ${ }^{\mathrm{b}}$, Siriphorn Rotarayanont ${ }^{\mathrm{a}}$, Jamnong Uthaibutra ${ }^{\mathrm{a}, \mathrm{c}}$, \\ Danai Boonyakiat ${ }^{\mathrm{c}, \mathrm{d}}$, Kobkiat Saengnil ${ }^{\mathrm{a}, \mathrm{c}, *}$ \\ a Department of Biology, Faculty of Science, Chiang Mai University, Chiang Mai 50200 Thailand \\ b Department of Biology, Mahidol Wittayanusorn School, Salaya, Phutthamonthon, \\ Nakhon Pathom 73170 Thailand \\ c Postharvest Technology Research Institute, Chiang Mai University, Chiang Mai 50200 Thailand and \\ Postharvest Technology Innovation Center, Commission on Higher Education, Bangkok 10400 Thailand \\ d Department of Plant Science and Natural Resources, Faculty of Agriculture, Chiang Mai University, \\ Chiang Mai 50200 Thailand
}

*Corresponding author, e-mail: kobkiat_s@hotmail.com

ABSTRACT: The effects of salicylic acid (SA) on reactive oxygen species (ROS) and the antioxidant defence system of mango fruits cv. Nam Dok Mai No. 4 in cold storage were evaluated. Mature mangos were dipped in $1 \mathrm{mM} \mathrm{SA}$ and distilled water (as control) for $10 \mathrm{~min}$ and stored at $5 \pm 1{ }^{\circ} \mathrm{C}$ with $90 \pm 2 \% \mathrm{RH}$ for 42 days. Chilling injury (CI) and ROS levels including superoxide radical $\left(\mathrm{O}_{2}^{--}\right)$, hydrogen peroxide $\left(\mathrm{H}_{2} \mathrm{O}_{2}\right)$ and hydroxyl radical ( $\left.\left.\mathrm{HO}\right)^{-}\right)$in the exocarp were measured every 7 days. The level of antioxidant system components, viz., enzymatic antioxidants: enzyme activity and gene expression of superoxide dismutase (SOD), catalase (CAT) and ascorbate peroxidase (APX); and nonenzymatic antioxidants: ascorbic acid, total glutathione and total phenolic contents, total antioxidant capacity (TAC) were determined. In the control fruits, the levels of $\mathrm{O}_{2}^{--}, \mathrm{H}_{2} \mathrm{O}_{2}$ and $\mathrm{HO}$ increased during storage with a decrease in ascorbic acid and total glutathione contents, while total phenolic content, TAC, enzyme activities, and gene expression of SOD, CAT, and APX increased during the first 21 days of storage but thereafter gradually decreased. CI symptoms appeared in the control fruits on day 21 and rapidly increased thereafter. During storage, SA-treated mango fruits exhibited significantly higher activities of SOD, CAT, and APX; and increased levels of ascorbic acid, total glutathione, total phenolic compounds, and TAC compared to that of the control fruits. High activities of antioxidant enzymes were associated with higher gene expression, which was correlated with the reduction of $\mathrm{CI}$ in SA-treated fruits. We conclude that during cold storage, the SA-treatment strengthens the antioxidant defence system reducing $\mathrm{CI}$ in mango fruits $\mathrm{cv}$. Nam Dok Mai No. 4 during cold storage.

KEYWORDS: chilling injury, oxidative stress, antioxidant enzyme, antioxidant capacity

\section{INTRODUCTION}

Oxidative stress, from excess reactive oxygen species (ROS) such as the superoxide radical $\left(\mathrm{O}_{2}^{--}\right)$, hydrogen peroxide $\left(\mathrm{H}_{2} \mathrm{O}_{2}\right)$, and hydroxyl radical $\left(\mathrm{HO}^{*}\right)$, is one of the main problems during storage of fruits and vegetables at low temperature ${ }^{1}$. ROS causes inactivation of enzymes, lipid peroxidation, protein degradation, and DNA damage resulting in cell membrane breakdown and finally visible chilling injury (CI) symptoms ${ }^{1,2}$. An increase in ROS together with CI has been reported in loquat, peach, cucumber, and kiwi fruits during low temperature storage ${ }^{3-6}$. For example, peaches stored at
$0{ }^{\circ} \mathrm{C}$ for 35 days, show an increase in $\mathrm{H}_{2} \mathrm{O}_{2}$ along with a decrease in catalase (CAT) and ascorbate peroxidase (APX) activities and total phenolic and ascorbic acid contents resulting in CI symptoms ${ }^{4}$. Cucumbers stored at $2{ }^{\circ} \mathrm{C}$ show an accumulation of $\mathrm{O}_{2}^{--}$and $\mathrm{H}_{2} \mathrm{O}_{2}$ along with an increase in superoxide dismutase (SOD) and APX activities ${ }^{5}$. The enzyme activities however decreased after day 6 of storage, resulting in the CI symptoms. Similarly, kiwi fruits stored at $0^{\circ} \mathrm{C}$ show an increase in $\mathrm{H}_{2} \mathrm{O}_{2}$ and $\mathrm{O}_{2}^{--}$ increased throughout, along with an initial increase in SOD, CAT, and APX activities decreasing after 10-40 days leading to CI symptoms ${ }^{6}$. Thus the reduction of damaging effects of chilling temperature 
in plants may be related to their ability to reduce and scavenge ROS, through enhancement of their antioxidant defence systems.

Salicylic acid (SA), an endogenous plant growth regulator, has been reported to have the ability to reduce ROS accumulation in fruits and vegetables during cold storage. For example, dipping lemon in $2 \mathrm{mM}$ SA solution for $30 \mathrm{~s}$ reduced ROS accumulation, reduced CI symptoms, but increases the antioxidant capacity during storage at $-0.5^{\circ} \mathrm{C}$ for 42 days $^{7}$. Treatments with SA derivatives, such as methyl salicylate (MeSA) and acetylsalicylic acid (ASA) also reduced CI symptoms of pomegranate during storage at $2{ }^{\circ} \mathrm{C}$ for 84 days, by increasing the total antioxidant capacity (TAC) and the contents of total phenolic compounds and anthocyanin ${ }^{8,9}$. Moreover, MeSA has been shown to induce the expression of $S O D, C A T$, and $A P X$ genes in tomato and sweet pepper, increasing the tolerance to $\mathrm{CI}^{10,11}$.

Mango cv. Nam Dok Mai No. 4 is an important fruit of Thailand that ripens quickly during transportation for export. Low temperature storage is an effective method to prolong the shelf life of Nam Dok Mai No. 4 mango fruits, but the fruits are susceptible to low temperature, causing CI symptoms within 21 days of storage at $5{ }^{\circ} \mathrm{C}^{12}$. Previous studies showed that dipping Nam Dok Mai No. 4 mango fruits in SA aqueous solution at $1 \mathrm{mM}$ significantly reduced CI symptoms and prolonged the storage life for 42 days with consumer acceptance ${ }^{12}$. In the present study, the effect of SA treatment on ROS accumulation and responses of antioxidant defence systems including enzymatic and non-enzymatic antioxidants, TAC and expression of antioxidant enzyme genes in Nam Dok Mai No. 4 mango fruits during cold storage were investigated to understand the mechanism by which SA increases chilling tolerance in mango fruit.

\section{MATERIALS AND METHODS}

\section{Plant materials}

Mango fruits cv. Nam Dok Mai No. 4 at commercial maturity (110 days after full bloom) were picked from a commercial orchard in Noen Maprang district, Phitsanulok province, Thailand and transported within $6 \mathrm{~h}$ to the Postharvest Physiology and Technology Research Laboratory at Chiang Mai University. Fruits were selected for uniform size, colour, absence of visual defects and then cleaned with tap water. To prevent postharvest infections, the fruits were dipped in $0.06 \mathrm{mM}$ azoxystrobin solution for $30 \mathrm{~s}$ and air-dried at ambient temperature. The fruits were randomly divided into two groups of 252 fruits for the treatment and the control. They were subdivided into 3 subgroups of 84 fruits each for three replications. For the treatment, the first group was dipped in $1 \mathrm{mM}$ SA solution for $10 \mathrm{~min}$ and the second group was dipped in distilled water for the control ${ }^{12}$. After dipping, the fruits were air-dried for $30 \mathrm{~min}$, and then stored at $5 \pm 1{ }^{\circ} \mathrm{C}$ with a relative humidity of $90 \pm 2 \%$. Twelve fruits from each subgroup were randomly sampled every 7 days for 42 days. The CI symptoms were determined. Exocarp tissue was removed and evaluated for changes in the levels of ROS $\left(\mathrm{O}_{2}^{--}, \mathrm{H}_{2} \mathrm{O}_{2}\right.$, and $\mathrm{HO}^{\circ}$ ), activities and gene expression of antioxidant enzymes (SOD, CAT, and APX), contents of ascorbic acid, total glutathione, total phenolic and TAC.

\section{CI index}

The degree of CI was expressed using the $\mathrm{CI}$ index ${ }^{13}$ with modifications. CI was scored by the percentage of surface area affected by exocarp browning compared with the total surface area, where $0=$ no visible browning, $1=1-10 \%$ browning, $2=11-$ $25 \%, 3=26-50 \%, 4=51-75 \%$ and $5=>75 \%$. CI index was determined for each treatment by multiplying the number of fruits in each category by their CI score and then dividing this by the total number of fruits.

\section{ROS levels}

$\mathrm{O}_{2}^{--}$content was determined using the protocol of Jiang et $\mathrm{al}^{14}$ with modifications. The exocarp tissue (1 g) was homogenized with a mortar and pestle at $4^{\circ} \mathrm{C}$ in $6 \mathrm{ml}$ of $65 \mathrm{mM} \mathrm{K}_{3} \mathrm{PO}_{4}$ buffer $\mathrm{pH} 7.8$. Then $2 \mathrm{ml}$ of $10 \mathrm{mM}$ hydroxylammonium chloride and $2 \mathrm{ml}$ of $0.1 \mathrm{M}$ ethylenediaminetetraacetic acid (EDTA) were added. The homogenate was centrifuged at $12000 \mathrm{~g}$ for $15 \mathrm{~min}$ at $4{ }^{\circ} \mathrm{C}$. Then $2 \mathrm{ml}$ of the supernatant with $2 \mathrm{ml}$ of $17 \mathrm{mM}$ 4-aminobenzenesulphonic acid were added to $2 \mathrm{ml}$ of $7 \mathrm{mM} \alpha$-naphthylamine. The mixture was placed in a water-bath at $40^{\circ} \mathrm{C}$ for 15 min before mixing with $2 \mathrm{ml}$ of ether. After centrifugation at $3000 \mathrm{~g}$ for $15 \mathrm{~min}$, the absorbance of the water phase was measured at $530 \mathrm{~nm}$. Standard curve was constructed with $\mathrm{NaNO}_{2}$, and the $\mathrm{O}_{2}^{--}$content was expressed as nmol/g fresh weight (FW).

$\mathrm{H}_{2} \mathrm{O}_{2}$ content was determined using the method of Velikova et al ${ }^{15}$ with modifications. The exocarp tissue ( $1 \mathrm{~g}$ ) was homogenized with a mortar and pestle in $5 \mathrm{ml}$ of $1 \%(\mathrm{w} / \mathrm{v})$ trichloroacetic acid (TCA) at $4^{\circ} \mathrm{C}$. The homogenate was centrifuged at $20000 \mathrm{~g}$ for $20 \mathrm{~min}$ at $4^{\circ} \mathrm{C}$, and $0.5 \mathrm{ml}$ of the 
supernatant was added to $2.4 \mathrm{ml}$ of $10 \mathrm{mM} \mathrm{K}_{3} \mathrm{PO}_{4}$ buffer $\mathrm{pH} 7.0$ and $0.1 \mathrm{ml}$ of $1 \mathrm{M} \mathrm{KI}$. The absorbance was measured at $390 \mathrm{~nm}$. Standard curve was constructed with different concentrations of $\mathrm{H}_{2} \mathrm{O}_{2}$ and the $\mathrm{H}_{2} \mathrm{O}_{2}$ content was expressed as $\mu \mathrm{mol} / \mathrm{g}$ FW.

$\mathrm{HO}^{\circ}$ content was determined using the protocol of Yang et $\mathrm{al}^{16}$ with modifications. The exocarp tissue $(1 \mathrm{~g})$ was homogenized in $15 \mathrm{ml}$ of $20 \mathrm{mM}$ $\mathrm{K}_{3} \mathrm{PO}_{4}$ buffer $\mathrm{pH} 6.0$ using a mortar and pestle at $4{ }^{\circ} \mathrm{C}$. The homogenate was centrifuged at $3000 \mathrm{~g}$ for $20 \mathrm{~min}$ at $4^{\circ} \mathrm{C}$, and $1 \mathrm{ml}$ of the supernatant was mixed with $1.5 \mathrm{ml}$ of $20 \mathrm{mM} \mathrm{K}_{3} \mathrm{PO}_{4}$ buffer $\mathrm{pH} 6.0$ containing $20 \mathrm{mM}$ 2-deoxy-D-ribose for $30 \mathrm{~min}$. Then $1 \mathrm{ml}$ of $0.5 \%(\mathrm{w} / \mathrm{v}) 2$-thiobarbituric acid containing $1.4 \%(\mathrm{w} / \mathrm{v})$ TCA was added. The mixture was heated in boiling water for $10 \mathrm{~min}$ and then cooled to room temperature. The absorbance of the mixture was measured at 532 and $553 \mathrm{~nm}$. The HOcontent was calculated from the extinction coefficient of $155 \mathrm{mM}^{-1} \mathrm{~cm}^{-1}$ and expressed as $\mathrm{nmol} / \mathrm{g}$ FW.

\section{Enzymatic activities}

Enzyme extraction and assays were performed using the method of Sunohara and Matsumoto ${ }^{17}$ with modifications. The exocarp tissue ( $1 \mathrm{~g})$ was ground in liquid nitrogen and homogenized using a mortar and pestle at $4{ }^{\circ} \mathrm{C}$ in $10 \mathrm{ml}$ of $25 \mathrm{mM} \mathrm{K}_{3} \mathrm{PO}_{4}$ buffer pH 7.8 containing $0.4 \mathrm{mM}$ EDTA, $1 \mathrm{mM}$ ascorbic acid, and $2 \%$ polyvinyl polypyrrolidone. The homogenate was centrifuged at $15000 \mathrm{~g}$ for $20 \mathrm{~min}$ at $4{ }^{\circ} \mathrm{C}$ and the supernatant was filtered through filter paper (Whatman no. 1, England). The filtrate was used as an enzyme extract for CAT (EC 1.11.1.6) and APX (EC 1.11.1.11) assays. For SOD (EC 1.15.1.1) assay, the enzyme extract was dialysed against regenerated cellulose tubular membrane (Cellu.Sep, USA) overnight with $10 \mathrm{mM} \mathrm{K}_{3} \mathrm{PO}_{4}$ buffer $\mathrm{pH} 7.8$ at $4^{\circ} \mathrm{C}$. The dialysed extract was centrifuged at $15000 \mathrm{~g}$ for $20 \mathrm{~min}$ at $4^{\circ} \mathrm{C}$. The supernatant was used as enzyme extract for SOD assay.

SOD activity was assayed in a $2 \mathrm{ml}$ reaction mixture containing $0.2 \mathrm{ml}$ of $500 \mathrm{mM} \mathrm{K}_{3} \mathrm{PO}_{4}$ buffer $\mathrm{pH} 7.8,0.2 \mathrm{ml}$ of $0.1 \mathrm{mM}$ cytochrome $\mathrm{C}$ from horse heart, $0.2 \mathrm{ml}$ of $1 \mathrm{mM}$ xanthine dissolved in $10 \mathrm{mM}$ $\mathrm{NaOH}, 0.04 \mathrm{ml}$ of xanthine oxidase, $1.32 \mathrm{ml}$ of distilled water and $0.04 \mathrm{ml}$ of enzyme extract. The rate of reduction in cytochrome $\mathrm{C}$ was measured by the initial rate of increase in absorbance at $550 \mathrm{~nm}$. The SOD activity was expressed as unit/mg protein.

CAT activity was assayed in a $2 \mathrm{ml}$ reaction mixture containing $1.9 \mathrm{ml}$ of $50 \mathrm{mM} \mathrm{K}_{3} \mathrm{PO}_{4}$ buffer $\mathrm{pH} 7.0$ containing $25 \mathrm{mM} \mathrm{H}_{2} \mathrm{O}_{2}$ and $0.1 \mathrm{ml}$ of enzyme extract. The subsequent decomposition of $\mathrm{H}_{2} \mathrm{O}_{2}$ was observed at $240 \mathrm{~nm}\left(\varepsilon=39.4 \mathrm{M}^{-1} \mathrm{~cm}^{-1}\right)$. The CAT activity was expressed as $\mu \mathrm{mol} \mathrm{H}_{2} \mathrm{O}_{2}$ decomposed (mg protein) ${ }^{-1} \mathrm{~min}^{-1}$.

APX activity was assayed in a $2 \mathrm{ml}$ reaction mixture, containing $0.5 \mathrm{ml}$ of $100 \mathrm{mM} \mathrm{K}_{3} \mathrm{PO}_{4}$ buffer $\mathrm{pH} 7.0,0.5 \mathrm{ml}$ of $1 \mathrm{mM}$ L-ascorbic acid (AA), $0.5 \mathrm{ml}$ of $0.4 \mathrm{mM}$ EDTA, $0.02 \mathrm{ml}$ of $10 \mathrm{mM} \mathrm{H}_{2} \mathrm{O}_{2}$, $0.38 \mathrm{ml}$ of distilled water, and $0.1 \mathrm{ml}$ of enzyme extract. The subsequent decrease in ascorbic acid was observed at $290 \mathrm{~nm}\left(\varepsilon=2.8 \mathrm{mM}^{-1} \mathrm{~cm}^{-1}\right)$. The APX activity was expressed as $\mu \mathrm{mol}$ AA decomposed (mg protein) ${ }^{-1} \mathrm{~min}^{-1}$.

The activity of each enzyme was expressed on a protein basis. Protein content was determined according to Lowry et $\mathrm{al}^{18}$, using bovine serum albumin as standard.

\section{Gene expressions of SOD, CAT, and APX}

RNA was isolated from exocarp tissue, according to the method of $\mathrm{Yu}$ and $\mathrm{Goh}^{19}$ with modifications. The exocarp tissue (100-200 mg) was ground in liquid nitrogen and extracted with $1.5 \mathrm{ml}$ of extraction buffer containing $2 \%(\mathrm{v} / \mathrm{v}) \beta$-mercaptoethanol, $2 \%(\mathrm{w} / \mathrm{v})$ hexadecyltrimethylammonium bromide, $100 \mathrm{mM}$ tris(hydroxymethyl)aminomethane hydrochloride $\mathrm{pH} 7.5,20 \mathrm{mM}$ EDTA, $2 \mathrm{M} \mathrm{NaCl}$ and $1 \%$ $(\mathrm{w} / \mathrm{v})$ polyvinylpyrrolidone. The homogenate was incubated in a water bath at $65^{\circ} \mathrm{C}$ for 15 min with occasional shaking. After centrifugation at $12000 \mathrm{~g}$ for $15 \mathrm{~min}$ at $4^{\circ} \mathrm{C}$, the aqueous phase was extracted at least twice with an equal volume of chloroform:isoamyl alcohol $(24: 1, \mathrm{v} / \mathrm{v})$. Total RNA was precipitated by adding 0.25 volume of $10 \mathrm{M} \mathrm{LiCl}$ to RNA solution and kept overnight on ice. The pellet was washed twice with $70 \%(\mathrm{v} / \mathrm{v})$ ethanol, dried, and dissolved in RNase-free water. RNA purity and concentration were determined spectrophotometrically.

Gene expression was determined using RT-PCR technique. First-strand cDNA was synthesized with ReverTra Ace- $\alpha$-cDNA synthesis kit (Toyobo, Japan) according to the manufacturer's instructions and used as a template in subsequent PCR reactions. Eight gene-specific primers (Table 1) were designed and used for amplification of the actin, SOD, CAT, and $A P X$ genes. Quick Taq HS DyeMix (Toyobo, Japan) was used to amplify specific genes according to the manufacturer's instructions. PCR amplification was carried out by 35 three-step cycles of $30 \mathrm{~s}$ denaturation at $94^{\circ} \mathrm{C}, 30 \mathrm{~s}$ annealing at $50-57^{\circ} \mathrm{C}$ and $50 \mathrm{~s}$ of elongation at $72^{\circ} \mathrm{C}$ and finally $5 \mathrm{~min}$ of elongation at $68^{\circ} \mathrm{C}$ in a thermal cycler. The actin 
Table 1 Specific primers used in the analysis of gene expression.

\begin{tabular}{llcc}
\hline Primers & Nucleotide sequence $\left(5^{\prime}-3^{\prime}\right)$ & $\begin{array}{c}T_{\mathrm{a}} \\
\left({ }^{\circ} \mathrm{C}\right)\end{array}$ & $\begin{array}{c}\text { Product } \\
\text { size }(\mathrm{bp})\end{array}$ \\
\hline SOD (F) & GCGATCAGTGGCGAGATCATGC & 50 & 468 \\
SOD (R) & CTGCAGGTAGTATGCATGCTCCC & & \\
CAT (F) & GAGGTGCCAGTGCCAAGGG & 56 & 602 \\
CAT (R) & CCACTCGGGGTAGTTTCCAGCAG & & \\
APX (F) & CCTATTATGCTTCGTCTTGCATGGC & 50 & 594 \\
APX (R) & GAAGGCATCTTCATCCGCAGC & & \\
Actin (F) & GGAACTGGTATGGTCAAGGC & 57 & 775 \\
Actin (R) & AGTCTCATGGATACCCGCAG & & \\
\hline
\end{tabular}

$T_{\mathrm{a}}=$ annealing temperature.

gene was amplified as control.

The semi-quantitative RT-PCR intensity value of the gene of interest in each sample was transformed to be a relative expression of the gene compared with actin expression by dividing it with an actin intensity value in each sample. Comparison of relative expressions of $S O D, C A T$, and $A P X$ with actin in the exocarp of control and SA-treated fruits during storage time (days $0,7,14,21,28,35$, and 42 ) was analysed using Scion Image 4.03 software. The PCR products of $S O D, C A T$, and $A P X$ genes were purified using HiYield Gel/PCR fragments extraction kit (Real Biotech Corporation, Taiwan) and sequenced by Macrogen, Korea. Identification of nucleotide sequences from RT-PCR was established using the NCBI BLAST program. Alignment and comparison of sequences were made using the CLUSTALW program.

\section{Ascorbic acid, total glutathione, and total phenolic contents}

Ascorbic acid content was determined according to Deepa et $\mathrm{al}^{20}$ and $\mathrm{AOAC}^{21}$ with modifications. Exocarp tissue $(2 \mathrm{~g}$ ) was homogenized in $10 \mathrm{ml}$ of $3 \%(\mathrm{w} / \mathrm{v})$ metaphosphoric acid using a mortar and pestle at $4{ }^{\circ} \mathrm{C}$. The homogenate was centrifuged at $3000 \mathrm{~g}$ for $20 \mathrm{~min}$ at $4^{\circ} \mathrm{C}$ and $2 \mathrm{ml}$ of the supernatant was added to $5 \mathrm{ml}$ of $3 \%$ metaphosphoric acid and then titrated with $0.1 \mathrm{mM} \mathrm{2,6-dichloroindophenol}$ (DPIP) for end point. The ascorbic acid content was expressed as mg AA/g FW.

Total glutathione content was determined according to Gronwald et $\mathrm{al}^{22}$ with modifications. Exocarp tissue $(1 \mathrm{~g})$ was homogenized in $12 \mathrm{ml}$ of $5 \%(\mathrm{w} / \mathrm{v})$ TCA using a mortar and pestle at $4^{\circ} \mathrm{C}$. The homogenate was centrifuged at $12000 \mathrm{~g}$ for $10 \mathrm{~min}$ at $4^{\circ} \mathrm{C}$. The supernatant was diluted to $1: 1$ with $0.5 \mathrm{M} \mathrm{K}_{3} \mathrm{PO}_{4}$ buffer $\mathrm{pH} 8.0$ and this dilution was further diluted to $1: 9$ in $0.1 \mathrm{M} \mathrm{K}_{3} \mathrm{PO}_{4}$ buffer $\mathrm{pH}$ 8.0. The reaction medium consisted of $2.2 \mathrm{ml}$ of $0.1 \mathrm{M} \mathrm{K}_{3} \mathrm{PO}_{4}$ buffer $\mathrm{pH} 7.5$ containing
$5 \mathrm{mM}$ EDTA, and $0.2 \mathrm{ml}$ of $1 \mathrm{mM}$ nicotinamide adenine dinucleotide phosphate (NADPH) prepared in $0.1 \mathrm{M} \mathrm{K}_{3} \mathrm{PO}_{4}$ buffer $\mathrm{pH} 7.5$ containing $5 \mathrm{mM}$ EDTA and $0.2 \mathrm{ml}$ (1 unit) of glutathione reductase (GR) prepared in $0.1 \mathrm{M} \mathrm{K}_{3} \mathrm{PO}_{4}$ buffer $\mathrm{pH}$ 7.5. These components were equilibrated in test tubes at $25^{\circ} \mathrm{C}$ for $2 \mathrm{~min}$. The reaction was initiated by adding $0.2 \mathrm{ml}$

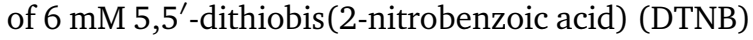
prepared in $0.1 \mathrm{M} \mathrm{K}_{3} \mathrm{PO}_{4}$ buffer $\mathrm{pH} 7.5$, and $0.2 \mathrm{ml}$ of diluted supernatant. The change in absorbance at $412 \mathrm{~nm}$ was measured every $1 \mathrm{~min}$ for $5 \mathrm{~min}$. The rate of change in absorbance was used to calculate total glutathione content. A standard curve was constructed with reduced glutathione (GSH) and the total glutathione content was expressed as $\mu \mathrm{g}$ GSH/g FW.

Total phenolic content was determined by the Folin-Ciocalteu method, according to the procedure of Singleton and Rossi ${ }^{23}$ with modifications. Exocarp tissue $(1 \mathrm{~g})$ was homogenized in $10 \mathrm{ml}$ of $80 \%$ ethanol using a mortar and pestle at $4{ }^{\circ} \mathrm{C}$. The homogenate was centrifuged at $16000 \mathrm{~g}$ for $20 \mathrm{~min}$ at $4{ }^{\circ} \mathrm{C}$ and $0.4 \mathrm{ml}$ of the supernatant was mixed with $2 \mathrm{ml}$ of $10 \%$ Folin-Ciocalteu's phenol reagent for $8 \mathrm{~min}$. Then $1.6 \mathrm{ml}$ of $7.5 \% \mathrm{Na}_{2} \mathrm{CO}_{3}$ were added. The mixture was placed at room temperature for $2 \mathrm{~h}$. The absorbance was measured at $765 \mathrm{~nm}$. A standard curve was constructed with gallic acid (GA) and the total phenolic content was expressed as $\mathrm{mg} \mathrm{GA} / \mathrm{g} \mathrm{FW}$.

\section{Total antioxidant capacity}

Exocarp tissue $(1 \mathrm{~g})$ was homogenized in $10 \mathrm{ml}$ of $80 \%$ ethanol using a mortar and pestle at $4{ }^{\circ} \mathrm{C}$. The homogenate was centrifuged at $16000 \mathrm{~g}$ for $20 \mathrm{~min}$ at $4{ }^{\circ} \mathrm{C}$, and the supernatant was collected as a sample solution to determine the TAC using 1,1-diphenyl-2-picrylhydrazyl (DPPH) and 2,2'-azinobis(3-ethylbenzothiazoline-6-sulphonic acid) (ABTS) radical scavenging methods.

The DPPH radical scavenging activity was determined according to the method of Mun'im et al ${ }^{24}$ with modifications. Sample solution of $0.1 \mathrm{ml}$ was mixed with $0.4 \mathrm{ml}$ of $0.3 \mathrm{M}$ acetate buffer $\mathrm{pH} 5.5$, and $2.5 \mathrm{ml}$ of $0.12 \mathrm{mM} \mathrm{DPPH}^{\circ}$ in $100 \%$ methanol was added. The mixture was placed in the dark at room temperature $\left(25^{\circ} \mathrm{C}\right)$ for $30 \mathrm{~min}$. The absorbance was measured at $517 \mathrm{~nm}$. Trolox was used as standard antioxidant and analysed at the same time. The final results were calculated and expressed as $\mu \mathrm{mol}$ Trolox/g FW.

The ABTS radical scavenging activity was determined according to the method of Huang et $\mathrm{al}^{25}$ 


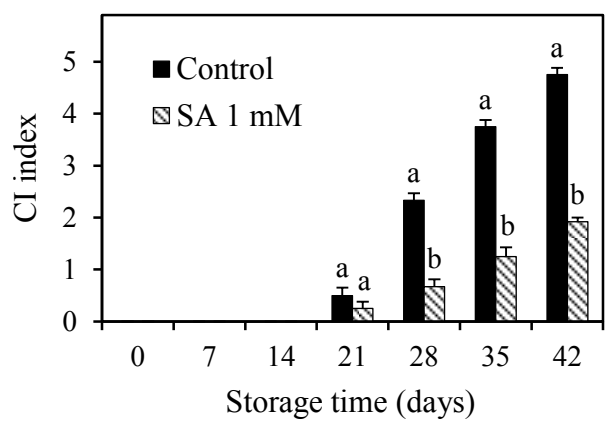

Fig. 1 Effect of SA on CI index of Nam Dok Mai No. 4 mango fruits during storage at $5{ }^{\circ} \mathrm{C}$.

with modifications. Sample solution of $0.02 \mathrm{ml}$ was mixed with $2 \mathrm{ml}$ of $\mathrm{ABTS}^{++}$solution prepared from $2 \mathrm{ml}$ of $7 \mathrm{mM} \mathrm{ABTS}$ added to $3 \mathrm{ml}$ of $2.45 \mathrm{mM}$ of potassium persulphate. The mixture was kept in the dark at $5{ }^{\circ} \mathrm{C}$ for $16 \mathrm{~h}$ to give a dark blue solution before being diluted with $80 \%$ ethanol until the absorbance at $734 \mathrm{~nm}$ was 0.7 . The mixture was placed at room temperature for $10 \mathrm{~min}$. The absorbance was measured at $734 \mathrm{~nm}$. Trolox was used as standard antioxidant and analysed at the same time. The final results were calculated and expressed as $\mu \mathrm{mol}$ Trolox/g FW.

\section{Statistical analysis}

All statistical analyses were performed using SPSS 17.0 statistical software (SPSS Incorporation Chicago, IL, USA). Data were presented as mean \pm standard error and analysed by one-way ANOVA. Mean separations were performed by Tukey's multiple range tests. Differences at $p<$ 0.05 were considered as significant. The correlation among variables was calculated by Pearson coefficient.

\section{RESULTS}

\section{Effect of SA on chilling injury}

CI symptoms in the control samples were first visible as exocarp browning within 21 days of storage (Fig. 1). The CI index of the control fruits progressed rapidly after 21 days (Fig. 1). Treatment with SA was effective for delaying the increase in $\mathrm{CI}$ symptoms, and lowering the CI index to about 70-80\% compared with the control fruits during days 28-42 of storage (Fig. 1).

\section{Effect of SA on $\mathrm{O}_{2}^{--}, \mathrm{H}_{2} \mathrm{O}_{2}$, and $\mathrm{HO} \cdot$ levels}

The levels of $\mathrm{O}_{2}^{--}, \mathrm{H}_{2} \mathrm{O}_{2}$, and $\mathrm{HO}$ increased with storage time in the control samples (Fig. 2). Both
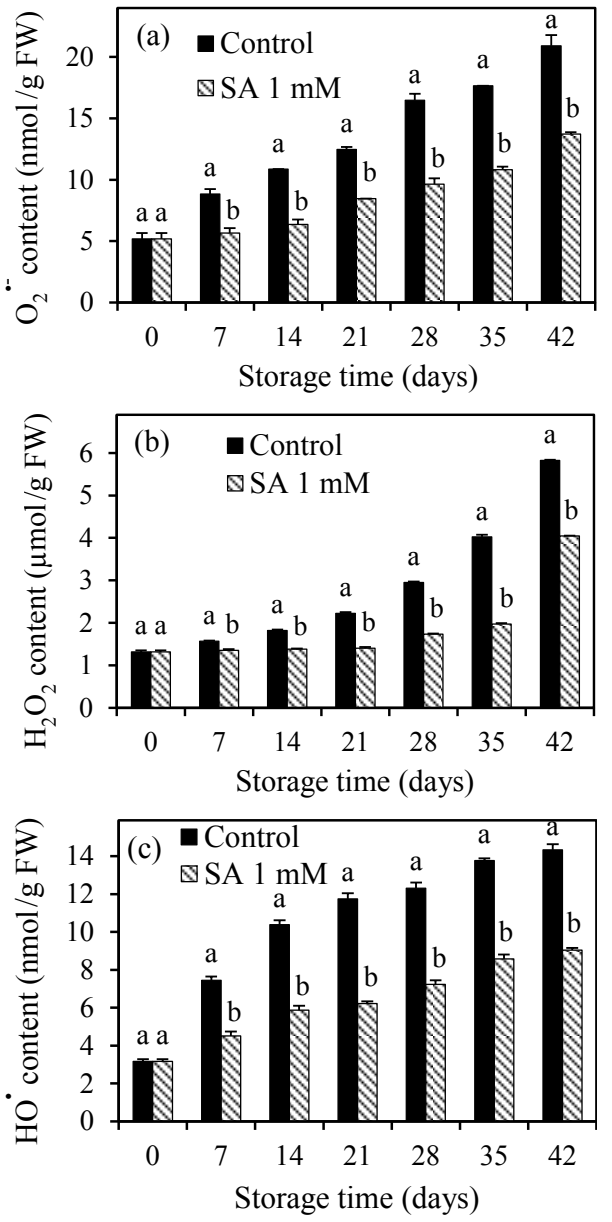

Fig. 2 Effect of SA on (a) $\mathrm{O}_{2}^{--}$, (b) $\mathrm{H}_{2} \mathrm{O}_{2}$, and (c) $\mathrm{HO}$ contents of Nam Dok Mai No. 4 mango fruits during storage at $5{ }^{\circ} \mathrm{C}$.

$\mathrm{O}_{2}^{--}$and $\mathrm{HO}$ levels increased rapidly over 42 days of storage (Fig. 2a and Fig. 2c), whereas the $\mathrm{H}_{2} \mathrm{O}_{2}$ level increased slightly during the first 21 days; then it increased rapidly thereafter (Fig. 2b). The level of $\mathrm{H}_{2} \mathrm{O}_{2}$ was higher than $\mathrm{O}_{2}^{--}$and $\mathrm{HO}^{-}$during the entire storage time. Treatments with SA significantly reduced $\mathrm{O}_{2}^{--}, \mathrm{H}_{2} \mathrm{O}_{2}$, and $\mathrm{HO}^{-}$levels (Fig. 2). The levels of $\mathrm{O}_{2}^{--}, \mathrm{H}_{2} \mathrm{O}_{2}$, and $\mathrm{HO}$ in SA-treated fruits were $32-41 \%$, $14-51 \%$, and $37-43 \%$, respectively, lower than those in the control fruits, throughout the cold storage.

\section{Effect of SA on activities of SOD, CAT, and APX}

The activities of SOD, CAT and APX in the control samples increased and reached the highest peak on days 7,21 , and 28 for CAT, SOD and APX, respectively, and then decreased gradually during the remainder of the storage period (Fig. 3). The 

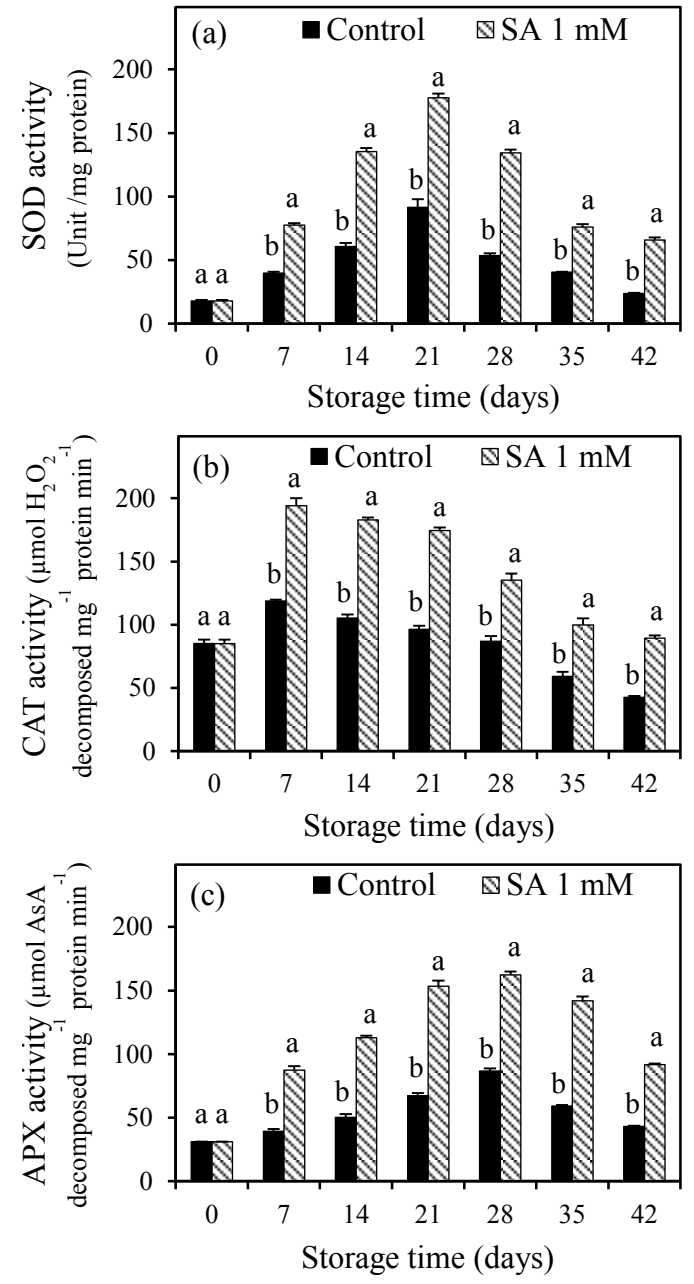

Fig. 3 Effect of SA on (a) SOD, (b) CAT, and (c) APX activities of Nam Dok Mai No. 4 mango fruits during storage at $5^{\circ} \mathrm{C}$.

increase in SOD activity was higher than APX and CAT when compared with day 0 (Fig. 3). Treatments with SA significantly increased the activities of SOD, CAT, and APX by $88-176 \%, 56-110 \%$, and $87-140 \%$, respectively, compared with the control fruits during the entire period of storage (Fig. 3).

\section{Effect of SA on expression of SOD, CAT, and APX genes}

To determine that SA directly affects $S O D, C A T$, and $A P X$ genes mRNA levels, the RT-PCR technique was used for gene expression analysis. In the control fruits, the SOD, CAT, and APX mRNA levels were initially high and reached a maximum on days 21 , 7, and 28, respectively (Fig. 4). They decreased gradually to a low level during the remaining time of storage.
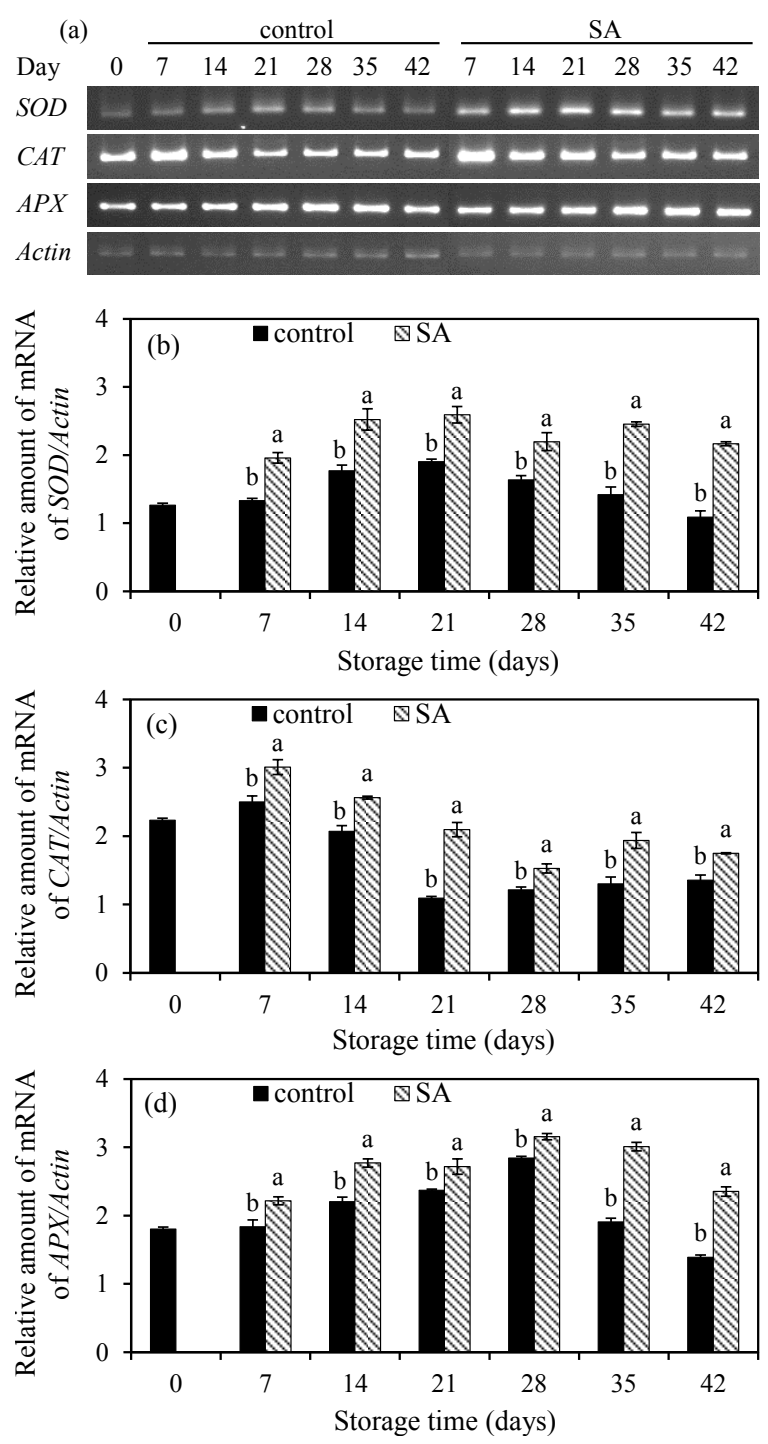

Fig. 4 (a) Effect of SA on expression of SOD, CAT, and $A P X$ genes in exocarp of Nam Dok Mai No. 4 mango fruits during storage at $5^{\circ} \mathrm{C}$. The PCR products were separated on $1.2 \%$ agarose gel electrophoresis. Actin was used as control. Relative expression levels of the (b) SOD, (c) CAT, and (d) APX genes compared with actin.

SA treatment also significantly promoted an increase and delayed the decrease in the expression of $S O D, C A T$, and $A P X$ genes (Fig. 4). The expression levels of $S O D, C A T$, and $A P X$ mRNA were significantly higher in SA-treated fruits than those in the control fruits during the entire storage period (Fig. 4). SA treatment greatly increased the mRNA expression level of SOD by 34-99\% compared with the control fruits throughout storage (Fig. 4b). SA treatment also showed $20-91 \%$ and $11-69 \%$ in- 

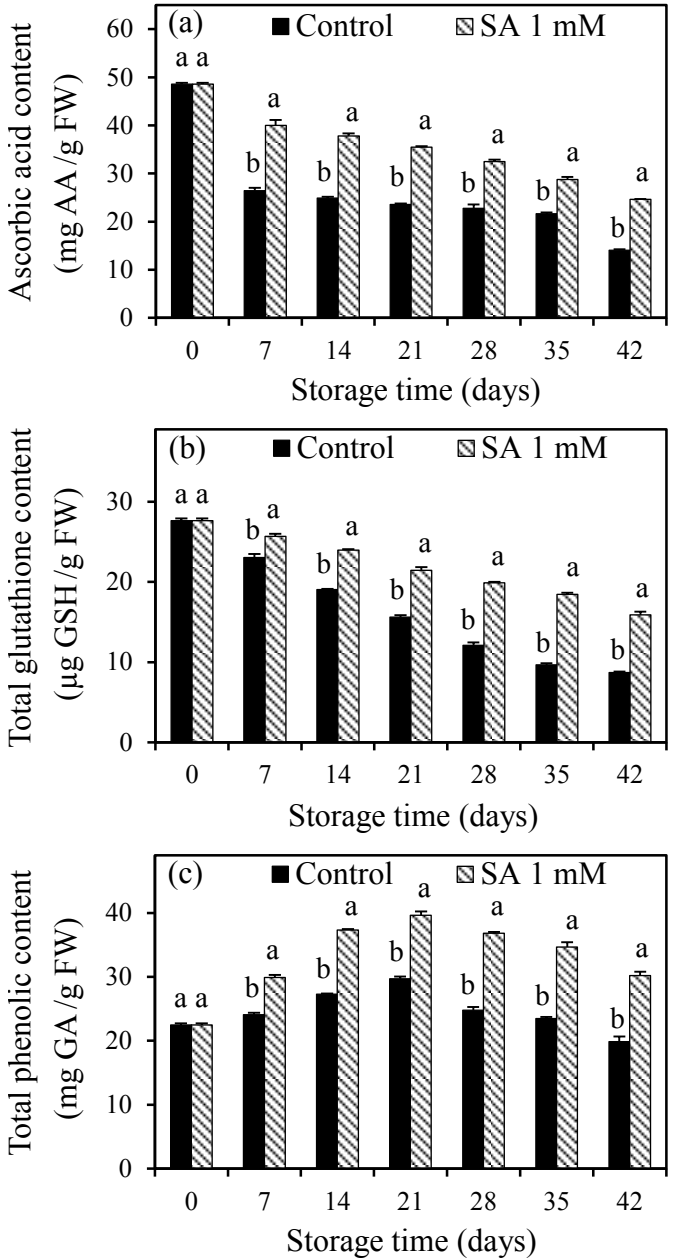

Fig. 5 Effect of SA on (a) ascorbic acid, (b) total glutathione, and (c) total phenolic contents of Nam Dok Mai No. 4 mango fruits during storage at $5^{\circ} \mathrm{C}$.

crease in the expression levels of $C A T$ and $A P X$ mRNA, but was less effective than $S O D$ (Fig. $4 \mathrm{c}$ and Fig. 4d).

\section{Effect of SA on ascorbic acid, total glutathione and total phenolic contents}

The amount of ascorbic acid and total glutathione in the control samples decreased continuously with storage time (Fig. 5a and Fig. 5b). Ascorbic acid decreased markedly for the first 7 days and slightly so thereafter (Fig. 5a). Glutathione gradually decreased, after being exposed to low temperature (Fig. 5b). At the end of storage, ascorbic acid and total glutathione contents declined by $70 \%$, compared with day 0 (Fig. 5a and Fig. 5b). Total phenolic content of the control fruits initially increased and reached the peak value on day 21 and
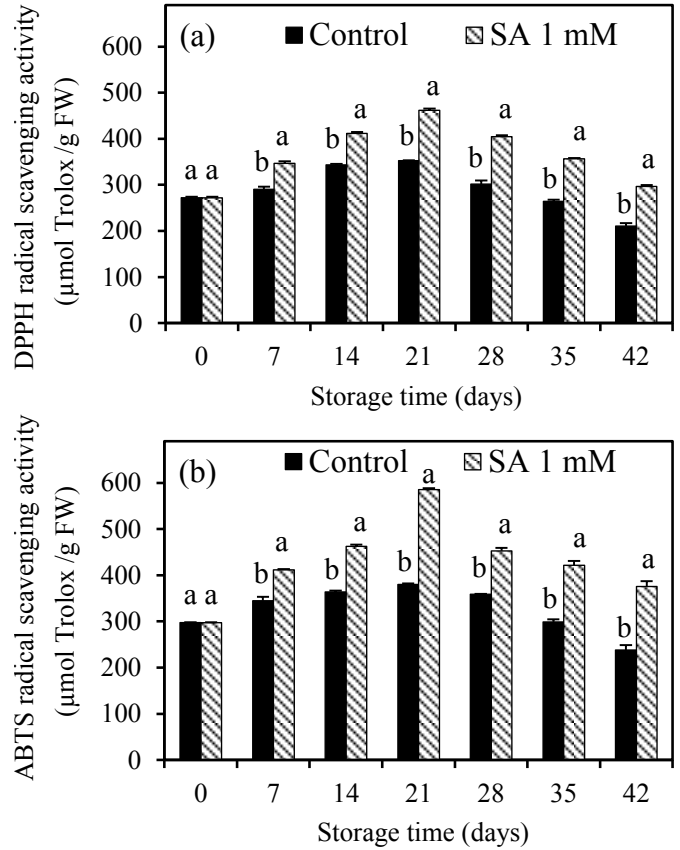

Fig. 6 Effect of SA on TAC by (a) DPPH and (b) ABTS radical scavenging activity methods of Nam Dok Mai No. 4 mango fruits during storage at $5^{\circ} \mathrm{C}$.

decreased gradually thereafter. Only about $12 \%$ of total phenolic content reduction was found on day 42 (Fig. 5c).

Treatments with SA significantly delayed the decrease of both ascorbic acid and total glutathione contents (Fig. 5a and Fig. 5b) and promoted the increase as well as delayed the decrease in total phenolic content during storage (Fig. 5c). There were higher amounts of ascorbic acid, total glutathione and total phenolic contents in SA-treated fruits during the entire storage period (Fig. 5). The contents of ascorbic acid, total glutathione and total phenolic compounds in SA-treated fruits were $33-75 \%, 11-91 \%$, and $24-52 \%$, respectively, higher than those in the control fruits throughout the cold storage (Fig. 5).

\section{Total antioxidant capacity}

Changes in TAC by both DPPH and ABTS radical scavenging activity methods in the control samples exhibited a similar pattern during storage (Fig. 6). The TAC of fruits treated with both methods increased continuously during the first 21 days and then decreased gradually during the remaining time of storage (Fig. 6). ABTS method showed higher antioxidant capacity than the DPPH method (Fig. 6).

SA treatment significantly promoted an increase 
and delayed the decrease in both methods of TAC measurement (Fig. 6). The TAC of SA-treated fruits by DPPH and ABTS methods were $18-41 \%$ and $20-58 \%$, respectively; higher than those of the control fruits during the entire storage period (Fig. 6).

\section{DISCUSSION}

Nam Dok Mai No. 4 mango fruits showed CI symptoms on day 21 during storage at $5{ }^{\circ} \mathrm{C}$ (Fig. 6). This result is consistent with our previous finding ${ }^{12}$. Fig. 1 and Fig. 2 showed that the increase in $\mathrm{O}_{2}^{--}$, $\mathrm{H}_{2} \mathrm{O}_{2}$, and $\mathrm{HO} \cdot$ levels appeared before CI symptoms suggesting that oxidative stress from excess of ROS is an early response of mango fruits to CI. This oxidative stress initiates membrane degradation, causing oxidative damage to DNA, proteins, and lipid membranes ${ }^{1}$. An increase in malondialdehyde content, a secondary end product of lipid peroxidation in membranes, has been observed to occur in exocarp of Nam Dok Mai No. 4 mango during the development of $\mathrm{CI}$ symptoms at $5{ }^{\circ} \mathrm{C}$ as a result of ROS accumulation ${ }^{12}$.

Generally, plants have evolved an efficient antioxidant defence system that can prevent the accumulation of ROS and repair oxidative damage when exposed to low temperatures stress ${ }^{2}$. In Nam Dok Mai No. 4 mango fruits, the levels of $\mathrm{O}_{2}^{--}, \mathrm{H}_{2} \mathrm{O}_{2}$, and $\mathrm{HO}^{*}$ are likely to be scavenged by increasing the activities of SOD, CAT, and APX that correlated with increasing of gene expression of these enzymes when exposed to low temperature stress (Fig. 3 and Fig. 4). However, genes expression and activities of these antioxidant enzymes were reduced upon longer storage with a concomitant increase in CI.

Ascorbic acid, glutathione and phenolic compounds act as ROS scavenger by donating electrons or hydrogen atoms to $\mathrm{ROS}^{2}$. The reduction in ascorbic acid, total glutathione, and total phenolic compounds associated with an increase in ROS during CI development is shown in Fig. 1 and Fig. 5. CI appears to be related to a loss of antioxidant functions. The decrease in TAC by both DPPH and ABTS methods that determine non-enzymatic antioxidant capacity after day 21 was accompanied by a reduction in both antioxidants associated with chilling damage (Fig. 6). These results indicate that CI symptoms appeared after the mango fruit exocarp has lost the ability to reduce and scavenge ROS by both enzymatic and non-enzymatic antioxidants, especially SOD, APX, and phenolic compounds.

This study shows that mango fruits treated with SA significantly reduced the accumulation of ROS and delayed the CI symptoms (Fig. 1 and Fig. 2). SA treatment also reduces $\mathrm{H}_{2} \mathrm{O}_{2}$ content and CI symptoms of the leaves of eggplant seedlings stored at $4{ }^{\circ} \mathrm{C}^{26}$. Moreover, loquat fruit treated with ASA and stored at $0^{\circ} \mathrm{C}$ also show reduced $\mathrm{O}_{2}^{--}$accumulation and CI symptoms ${ }^{27}$.

SA acts as a signal molecule with the ability to activate $S O D, C A T$, and $A P X$ genes expression that respond to chilling stress (Fig. 4). SA induce the expression of abiotic stress protective genes by activating mitogen-activated protein kinases (MAPKs) ${ }^{28}$. MAPK cascades constitute major pathways for signal transduction into intracellular response to activate transcription factors and induce the expression of genes that respond to stress ${ }^{28}$. The increase in expression of SOD, CAT, and APX genes was significantly high $(p=0.01)$ and positively correlated with the increase in their corresponding enzymatic activities in SA-treated fruits $(r=0.879,0.678$, and 0.886 , respectively) (data not shown). The enhancement and maintenance the high activity of SOD, CAT, and APX lead to a reduction of ROS accumulation and CI symptoms in Nam Dok Mai No. 4 mango fruits by SA (Fig. 1, Fig. 2, and Fig. 3). Accordingly, dipping peaches in $1 \mathrm{mM}$ SA enhances GR activity but delay the decrease in APX activity associated with reducing CI during cold storage ${ }^{29}$. This agrees with the reported high SOD, CAT, and $A P X$ genes expression activated by MeSA vapour treatment that induces $\mathrm{CI}$ tolerance in tomato ${ }^{10}$ and sweet pepper ${ }^{11}$, respectively.

For non-enzymatic antioxidants, the higher content of phenolic compounds in SA-treated fruit may be associated with induction of phenolic biosynthesis by SA (Fig. 5c). SA may activate phenylalanine ammonia-lyase (PAL), the first key enzyme in phenolic biosynthesis, which results in the accumulation of phenolic compounds. In agreement with this idea, PAL activity of grape berry ${ }^{30}$ and cornelian cherry $^{31}$ increase after SA treatment. The higher content of ascorbic acid in SA-treated fruits may also result from an inhibition degradation induced by SA (Fig. 5a). SA may inhibit the activity of ascorbic acid oxidase (AAO), the enzyme responsible for ascorbic acid oxidation and caused a loss of ascorbic acid. Accordingly, sweet pepper treated with SA and stored at 10 and $25^{\circ} \mathrm{C}$ showed lower AAO activity than the control fruit ${ }^{32}$. To maintain the glutathione content of mango exocarp (Fig. 5b), SA may activate GR, the enzyme responsible for catalysing the NADPH dependent reduction of glutathione disulphide (oxidized glutathione, GSSG) to GSH, thus keeping GSH, total glutathione, and GSH/GSSG levels high. This is supported by the observation that peaches 
treated with SA and stored in cold have increased GR activities with higher GSH, total glutathione, and GSH/GSSG ratios ${ }^{29}$. The higher contents of ascorbic acid, total glutathione, and total phenolic compounds were associated with an increase in TAC in SA-treated fruits, leading to a reduction in ROS accumulation and CI symptoms (Fig. 6). Accordingly, dipping pomegranate in $1 \mathrm{mM}$ ASA and vaporizing with $0.01-0.1 \mathrm{mM}$ MeSA also reduce CI symptoms of by enhancing TAC, total phenolic compounds, and total anthocyanin contents during cold storage ${ }^{8,9}$.

In conclusion, Nam Dok Mai No. 4 mango fruit treated with $1 \mathrm{mM}$ SA showed a decreased $\mathrm{O}_{2}^{--}$, $\mathrm{H}_{2} \mathrm{O}_{2}$, $\mathrm{HO} \cdot$ accumulation by inducing gene expression and enzyme activity of SOD, CAT, and APX in the fruit exocarp during cold storage at $5^{\circ} \mathrm{C}$. SA treatment also maintained higher contents of phenolic compounds, ascorbic acid, and glutathione, and increased the antioxidant capacity. All of these effects contribute to a mechanism by which SA enhances chilling tolerance in mango fruit during cold storage.

Acknowledgements: This study was supported by the Faculty of Science and the Graduate School, Chiang Mai University, Chiang Mai, Thailand.

\section{REFERENCES}

1. Shewfelt RL, del Rosario BA (2000) The role of lipid peroxidation in storage disorders of fresh fruits and vegetables. Hortscience 35, 575-9.

2. Mittler R (2002) Oxidative stress, antioxidants and stress tolerance. Trends Plant Sci 7, 405-10.

3. Cao S, Zheng Y, Wang K, Jin P, Rui H (2009) Methyl jasmonate reduces chilling injury and enhances antioxidant enzyme activity in postharvest loquat fruit. Food Chem 115, 1458-63.

4. Jin P, Wang K, Shang H, Tong J, Zheng Y (2009) Lowtemperature conditioning combined with methyl jasmonate treatment reduces chilling injury of peach fruit. J Sci Food Agr 89, 1690-6.

5. Yang H, Wu F, Cheng J (2011) Reduced chilling injury in cucumber by nitric oxide and the antioxidant response. Food Chem 127, 1237-42.

6. Yang Q, Zhang Z, Rao J, Wang Y, Sun Z, Ma Q, Dong X (2013) Low-temperature conditioning induces chilling tolerance in 'Hayward' kiwifruit by enhancing antioxidant enzyme activity and regulating en-dogenous hormones levels. J Sci Food Agr 93, 3691-9.

7. Siboza XI, Bertling I (2013) The effects of methyl jasmonate and salicylic acid on suppressing the production of reactive oxygen species and increasing chilling tolerance in 'Eureka' lemon [Citrus limon (L.) Burm. F.]. J Hort Sci Biotechnol 88, 269-76.

8. Sayyari M, Babalar M, Kalantari S, Martínez-Romero D, Guillén F, Serrano M, Valero D (2011) Vapour treatments with methyl salicylate or methyl jasmonate alleviated chilling injury and enhanced antioxidant potential during postharvest storage of pomegranates. Food Chem 124, 964-70.

9. Sayyari M, Castillo S, Valero D, Díaz-Mula HM, Serrano M (2011) Acetyl salicylic acid alleviates chilling injury and maintains nutritive and bioactive compounds and antioxidant activity during postharvest storage of pomegranates. Postharvest Biol Tech 60, 136-42.

10. Ding CK, Wang CY, Gross KC, Smith DL (2002) Jasmonate and salicylate induce the expression of pathogenesis-related-protein genes and increase resistance to chilling injury in tomato fruit. Planta 214, 895-901.

11. Fung RWM, Wang CY, Smith DL, Gross KC, Tian M (2004) MeSA and MeJA increase steady-state transcript levels of alternative oxidase and resistance against chilling injury in sweet peppers (Capsicum annuum L.). Plant Sci 166, 711-9.

12. Junmatong C, Uthaibutra J, Boonyakiat D, Faiyue B, Saengnil K (2012) Reduction of chilling injury of 'Nam Dok Mai No. 4' mango fruit by treatments with salicylic acid and methyl jasmonate. J Agr Sci 4, 126-36.

13. Zhao Z, Jiang W, Cao J, Zhao Y, Gu Y (2006) Effect of cold-shock treatment on chilling injury in mango (Mangifera indica L. cv. 'Wacheng') fruit. $J$ Sci Food Agr 86, 2458-62.

14. Jiang L, Hou T, Yuan X, Jiang J, Yu Z (2010) Effect of storage temperature and packaging method on the decay and physiology of fresh leaves of Gynura bicolor D.C. J Food Process Preserv 34, 858-71.

15. Velikova V, Yordanov I, Edreva A (2000) Oxidation stress and some antioxidant systems in acid raintreated bean plants: protective role of exogenous polyamines. Plant Sci 151, 59-66.

16. Yang S, Su X, Prasad KN, Yang B, Cheng G, Chen Y, Yang E, Jiang Y (2008) Oxidation and peroxidation of postharvest banana fruit during softening. Pakistan $J$ Bot 40, 2023-9.

17. Sunohara Y, Matsumoto H (2004) Oxidative injury induced by the herbicide quinclorac on Echinochloa oryzicola Vasing. and the involvement of antioxidative ability in its highly selective action in grass species. Plant Sci 167, 597-606.

18. Lowry $\mathrm{OH}$, Rosebrough NJ, Farr AL, Randall RJ (1951) Protein measurement with the folin phenol reagent. $J$ Biol Chem 193, 265-75.

19. Yu H, Goh CJ (2000) Identification and characterization of three orchid MADS-box genes of the AP1/AGL9 subfamily during floral transition. Plant Physiol 123, 1325-36. 
20. Deepa N, Kaur C, Singh B, Kapoor HC (2006) Antioxidant activity in some red sweet pepper cultivars. J Food Compos Anal 19, 572-8.

21. AOAC (1990) Official Methods of Analysis, 12th edn, Association of Official Agricultural Chemists, Washington, DC.

22. Gronwald JW, Fuerst EP, Eberlein CV, Egli MA (1987) Effect of herbicide antidotes on glutathione content and glutathione $S$-transferase activity of sorghum shoots. Pestic Biochem Physiol 29, 66-76.

23. Singleton VL, Rossi JA Jr (1965) Colorimetry of total phenolics with phosphomolybdic-phosphotungstic acid reagents. Am J Enol Viticult 16, 144-57.

24. Mun'im A, Negishi O, Ozawa T (2003) Antioxidative compounds from Crotalaria sessiliflora. Biosci Biotechnol Biochem 67, 410-4.

25. Huang D, Ou B, Prior RL (2005) The chemistry behind antioxidant capacity assays. $J$ Agr Food Chem 53, 1841-56.

26. Chen S, Zimei L, Cui J, Jiangang D, Xia X, Liu D, Yu J (2011) Alleviation of chilling-induced oxidative damage by salicylic acid pretreatment and related gene expression in eggplant seedlings. Plant Growth Regul 65, 101-8.

27. Cai C, Li X, Chen KS (2006) Acetylsalicylic acid alleviates chilling injury of postharvest loquat (Eriobotrya japonica Lindl.) fruit. Eur Food Res Tech 223, 533-9.

28. Yuan S, Lin HH (2008) Role of salicylic acid in plant abiotic stress. $Z$ Naturforsch 63, 313-20.

29. Wang L, Chen S, Kong W, Li S, Archbold DD (2006) Salicylic acid pretreatment alleviates chilling injury and affects the antioxidant system and heat shock proteins of peaches during cold storage. Postharvest Biol Tech 41, 244-51.

30. Wen PF, Chen JY, Kong WF, Pan QH, Wan SB, Huang WD (2005) Salicylic acid induced the expression of phenylalanine ammonia-lyase gene in grape berry. Plant Sci 169, 928-34.

31. Dokhanieh AY, Aghdam MS, Fard JR, Hassanpour H (2013) Postharvest salicylic acid treatment enhances antioxidant potential of cornelian cherry fruit. Sci Hort 154, 31-6.

32. Rao TVR, Gol NB, Shah KK (2011) Effect of postharvest treatments and storage temperatures on the quality and shelf life of sweet pepper (Capsicum annum L.). Sci Hort 132, 18-26. 